\title{
Mitogenic and functional responses by nicotine and hydrogen peroxide in AR42J cells: a comparative study Azida Walker ${ }^{1}$, Kodetthoor B Udupa ${ }^{1,2,3}$ and Parimal Chowdhury*1
}

\author{
Address: ${ }^{1}$ Department of Physiology and Biophysics, University of Arkansas for Medical Sciences, Little Rock, AR, USA, ${ }^{2}$ Department of Geriatrics, \\ University of Arkansas for Medical Sciences, Little Rock, AR, USA and ${ }^{3}$ Medical Research, Central Arkansas Veterans Healthcare System, Little Rock, \\ AR, USA \\ Email: Azida Walker - awalker@uams.edu; Kodetthoor B Udupa - udupakodetthoor@uams.edu; \\ Parimal Chowdhury* - PChowdhury@uams.edu \\ * Corresponding author \\ Published: 31 July 2008 \\ Tobacco Induced Diseases 2008, 4:5 doi:10.1 186/1617-9625-4-5 \\ Received: 13 June 2008 \\ Accepted: 31 July 2008 \\ This article is available from: http://www.tobaccoinduceddiseases.com/content/4/I/5 \\ (C) 2008 Walker et al; licensee BioMed Central Ltd. \\ This is an Open Access article distributed under the terms of the Creative Commons Attribution License (http://creativecommons.org/licenses/by/2.0), \\ which permits unrestricted use, distribution, and reproduction in any medium, provided the original work is properly cited.
}

\begin{abstract}
The aim of the current study was to investigate the oxidative effects of nicotine by examining the mitogenic and functional responses in AR42J cells. As a control and for comparison, hydrogen peroxide $\left(\mathrm{H}_{2} \mathrm{O}_{2}\right)$ was used as a source of known oxidative biomarker. Responses were examined by determining cell proliferation through the activation of ERK signaling, basal and CCK-stimulated cell function and measuring lipid peroxidation. AR42J cells have been exposed to either a noncytotoxic dose of $20 \mu \mathrm{M} \mathrm{H}_{2} \mathrm{O}_{2}$ for $15 \mathrm{~min}$ or to $100 \mu \mathrm{M}$ of nicotine for 3 min respectively. Nicotine and $\mathrm{H}_{2} \mathrm{O}_{2}$ at these dose and time intervals produced similar levels of malondialdyde (MDA) production and p-ERKI/2 activation. Immunofluorescence studies employing specific antibody to P-ERKI/2 confirmed the latter. Nicotine-induced increase in the proliferation of AR42J cells was significantly higher in comparison to $\mathrm{H}_{2} \mathrm{O}_{2}$ exposed cells. CCK-stimulated cell function induced by nicotine was significantly higher in AR42J cells as compared to the response by $\mathrm{H}_{2} \mathrm{O}_{2}$. These results suggest that nicotine- induced mitogenic and functional response in AR42J cells are associated with ERK signaling and increase in reactive oxygen species production. The data suggests that nicotineinduced mitogenic response in AR42J cells closely identifies the response induced by an oxidative biomarker.
\end{abstract}

\section{Background}

Nicotine, one of the main chemicals in tobacco, has been known as a primary psychoactive ingredient that is responsible for the reinforced behavior in smokers. Each year in the United States, 435,000, or 1 in every 5 deaths, are attributed to cigarette smoking [1]. About half of the young adult smokers today who continue to smoke throughout their life will die of a smoke related diseases [2]. Further, it has been shown that smoking is an independent risk factor in the development of chronic pancreatitis and pancreatic cancer $[3,4]$. In animal studies it has been shown that nicotine plays a role in the induction of pathophysiology of pancreas $[5,6]$.

Evidence shows that lipid peroxidation occurs in pancreatic tissues when exposed to nicotine [7] and that the mitochondrial respiratory chain is affected by nicotine leading to an increased generation of superoxide anions and hydrogen peroxide [8]. Clinical studies have indicated that patients with acute pancreatitis have a higher plasma levels of lipid peroxide than that observed in patients with mild pancreatitis [9]. This suggests that mul- 
tiple etiological factors other than the release of enzymes may be responsible in this mechanism. As of to-date, however, there have been no reported studies investigating the role of oxyradicals induced by nicotine in the pancreas, and to determine whether oxyradical formation by nicotine contribute to the pathophysiological mechanisms associated with pancreatic injury encountered in smokers We have shown earlier that nicotine induces functional alterations and MAP kinase signaling pathways in pancreatic acinar cells [10,11]; however, the underlying mechanisms responsible for these observed effects by nicotine are still not completely understood. We surmise in this study that nicotine induces the oxidative stress in pancreatic acinar cells and thus contributes to this mechanism.

Oxidative stress arises when there is an imbalance between the formation of reactive oxygen species (ROS) and removal of oxyradicals by scavenging antioxidants. Increase in ROS production has been directly linked to the oxidation of cellular macromolecules, which may cause direct cellular injury or induce a variety of cellular responses through the generation of secondary metabolic reactive species [12]. Clinical studies have shown that oxidative stress leading to lipid peroxidation appears to be linked to the pathogenesis of chronic pancreatitis [13]. Other evidence showing the production of large amounts of oxygen radicals in lymphocytes due to cigarette smoking [14] suggests that nicotine derived from cigarette smoking may play a role, in pathophysiological process.

The current study was designed to examine whether exposure of AR42J cells to nicotine causes the production of reactive oxygen species. Thus we have reexamined the mitogenic and functional responses of this cell line to nicotine and compared its effects with hydrogen peroxide $\left(\mathrm{H}_{2} \mathrm{O}_{2}\right)$, a known oxidative biomarker, in the same cellular system in order to evaluate the direct effect of oxidative stress in this cell line. The AR42J cell line was used because of its stability as an immortal tumor cell line and its known similarity in physiological characteristics to primary acinar cells [15].

\section{Materials and methods Cell Culture}

AR42J cells, a rat pancreatic tumor cell line, were obtained from ATCC (Rockville, MD). These cells were grown in 75 $\mathrm{cm}^{2}$ flasks with $12 \mathrm{ml}$ of Ham's F12 nutrient media with 2 $\mathrm{mM}$ L-glutamine and $1.5 \% \mathrm{NaHCO}_{3}(\mathrm{~F} 12 \mathrm{~K}$, obtained from Hyclone, Logan, UT), to which $10 \%$ fetal bovine serum (FBS) and $1 \%$ penicillin-streptomycin were added. The flasks were kept in an incubator maintained at $37^{\circ} \mathrm{C}$ with a $5 \% \mathrm{CO}_{2} / 95 \%$ air atmosphere until they reached over $80 \%$ confluency.

\section{Assay of Cell Cytotoxicity in the presence of $\mathrm{H}_{2} \mathrm{O}_{2}$}

The cytotoxic effect of $\mathrm{H}_{2} \mathrm{O}_{2}$ on the cells was measured using an LDH-Cytotoxicity Assay Kit from Biovision Research Products (Mountain View, CA). The kit consisted of a lyophilized catalyst and a dye reagent. The test samples were prepared with various doses of $\mathrm{H}_{2} \mathrm{O}_{2}$ ranging from $10-100 \mu \mathrm{M}$ and cell cytotoxicity measurements were performed following the recommendation of the manufacturer. The cytotoxicity study with nicotine varying doses has been reported previously in this cell system [10]. A dose of $100 \mu \mathrm{M}$ nicotine was found to be nontoxic. The percent of cytotoxic cells increased significantly beyond this dose level of nicotine. Thus this dose of nicotine was selected for this comparative study.

\section{Measurement of cellular lipid peroxidation products induced by $\mathrm{H}_{2} \mathrm{O}_{2}$ and nicotine}

Lipid peroxidation assay was conducted using MDA-586 method (Oxis Research, Portland, OR) with whole cell lysates obtained after treatment with nicotine or $\mathrm{H}_{2} \mathrm{O}_{2}$. Malondialdehyde (MDA, Sigma-Aldrich, St Louis, MO) was used as a standard. Both the standards and whole cell lysates were incubated for $1 \mathrm{~h}$ in a $45^{\circ} \mathrm{C}$ water bath with $\mathrm{N}$-methyl-2-phenylindole (NM2P, dissolved in acetonitrile) and diluted with methanol together with concentrated $\mathrm{HCl}$. The ratio of cell lysate to the volume of NM2P solution was 1:5. Methods of measurement of MDA from tissue homogenates and blood have been reported recently from our laboratory $[16,17]$.

\section{MAPK Signaling assay by Western Blot Analysis}

Whole cells lysates were prepared from flasks containing more than $80 \%$ confluent cells that were tyrpsinized. About 1-2 $\times 10^{6}$ cells were plated per flask. The cells were allowed to attach. The cells were incubated overnight in serum free media. Cells were treated with $100 \mu \mathrm{M}$ nicotine or $20 \mu \mathrm{M} \mathrm{H}_{2} \mathrm{O}_{2}$, washed with cold PBS and placed on ice. Two hundred fifty microliters of RIPA buffer containing PMSF/protease III cocktail inhibitor was added. The cells were lysed, sonicated and incubated on ice for $40 \mathrm{~min}$. The cell protein mixture was then spun down at 12,000 rpm for $10 \mathrm{~min}$; supernatant removed and kept on ice. Protein concentration was determined by Bradford assay with bovine serum-albumin as the standard [18].

For Western Blot analysis, a total of $40 \mu \mathrm{g}$ of cellular protein was loaded onto $12 \%$ SDS-polyacrylamide gels and electrophoresed for $1 / 12 \mathrm{~h}$ at a steady voltage of $120 \mathrm{~V}$. The separated protein bands were then transferred to nitrocellulose membranes (BioRad Laboratories, Hercules, CA). The primary antibodies used for probing the nitrocellulose membrane overnight were obtained from Cell Signaling (Danvers, MA). The antibodies used were: anti-ERK1/2, anti-pERK1/2. Subsequently membranes were probed with horseradish peroxidase-conjugated sec- 
ondary antibody (Pierce Biotechnology Inc, Rockford, IL). Enhanced chemiluminescence (ECL+, Amersham BioSciences, Piscatway, NJ) was used to visualize the bands. The band intensity was quantified using a STORM 860 Imager (Molecular Dynamics, Inc, Sunnyvale CA).

\section{Cell Proliferation Assay}

Cell proliferation studies were conducted after treatments with $100 \mu \mathrm{M}$ nicotine, or $20 \mu \mathrm{M} \mathrm{H}_{2} \mathrm{O}_{2}$ using commercially available Cell Viability and Cytotoxicity Assay Kit (Cell Counting Kit, CCK-8, Dojindo Molecular Technologies Inc. Gaithersburg, MD). Ninety six-well microplates were used and $2 \times 10^{4}$ cells per well were plated. The cells were allowed to attach for $24 \mathrm{~h}$ in media containing 10\% FBS. Following this, the cells were kept in $0.05 \%$ FBS containing media overnight before being treated with $100 \mu \mathrm{M}$ nicotine or $20 \mu \mathrm{M} \mathrm{H}_{2} \mathrm{O}_{2}$. Twenty $\mu \mathrm{l}$ of CCK-8 dye was added to each well at specified time interval and incubated further for $3 \mathrm{~h}$ at $37^{\circ} \mathrm{C}$. The absorbance was measured at $450 \mathrm{~nm}$.

\section{Localization of MAPK signals measured by Immunofluorescence Imaging}

For these studies, $4 \times 10^{4}$ cells per well were plated in 4 well Lab-Tek chamber slides (Becton Dickinson Labware, Franklin Lakes, NJ). The cells were allowed to attach for 24 $\mathrm{h}$ in $10 \%$ FBS media before transferring to serum free media overnight. The cells were then exposed to $100 \mu \mathrm{M}$ nicotine for $3 \mathrm{~min}$ or $20 \mu \mathrm{M} \mathrm{H}_{2} \mathrm{O}_{2}$ for $15 \mathrm{~min}$. After washing briefly with cold PBS, the cells were fixed with $2 \%$ paraformaldehyde for $20 \mathrm{~min}$ at room temperature, permeablized with $1 \%$ Triton X-100 in PBS for 5 min followed by extensive washing with PBS. Blocking was done using $1 \%$ bovine serum-albumin and 5\% goat serum in PBS. Incubation with primary antibody to p-ERK (1:100 dil) in $1 \%$ bovine serum-albumin was continued for $24 \mathrm{~h}$ at $4^{\circ} \mathrm{C}$. Following incubation the slides were washed 3 times, 10 min each with PBS. After washing, the cells were incubated with fluorescein isothiocyanate-conjugated anti-rabbit IgG antibody (1:50 dilution, Sigma, St. Louis $\mathrm{MO})$, at room temperature for $45 \mathrm{~min}$. Slides were then washed extensively ( 3 times for $10 \mathrm{~min}$ ) in PBS. Mounting media from Invitrogen Technologies (Carlsbad, CA) was used to mount the samples. The slides were then viewed under confocal microscope and images were analyzed using Fluorescan 2 software (Fluorescan Labsystems OY, Helsinki, Finland). The negative controls for immunostaining were cells that were unexposed and incubated with secondary antibody alone.

\section{Assay of basal and stimulated cell function by bioassay} For cell function studies, the cells were grown to $80 \%$ and above in confluency. The flasks containing an average 4-6 $\times 10^{6}$ cells, were washed with Hepes-Ringer Buffer (HRB) before treating with $100 \mu \mathrm{M}$ nicotine in HRB for 3 mins or
$20 \mu \mathrm{M} \mathrm{H}_{2} \mathrm{O}_{2}$ in HRB for $15 \mathrm{~min}$. After incubation the cells were washed with HRB. The cells were then trypsinized using $1 \times$ Trypsin EDTA (Mediatech Inc, Herndon, VA). 5 mls of HRB were then added and the cells were centrifuged for $5 \mathrm{~min}$ at $1000 \mathrm{rpm}$. The supernatant was discarded and the cells were resuspended in HRB. The resuspended cells were incubated with and without CCK $\left(10^{-10} \mathrm{M}\right)$ for $30 \mathrm{~min}$ at $37^{\circ} \mathrm{C}$. After the incubation, the media was removed following centrifugation. Amylase activity was measured employing procion yellow starch as substrate (PRO Chemical \& Dye; Somerset, MA) using the method of Jung [19]. The cell pellets were washed with ice cold PBS, lysed with water by sonication and centrifuged. The cell lysate was analyzed for both amylase and protein content.

\section{Statistical Analysis}

Experimental values are calculated as mean \pm SEM of the number of experiments indicated in the legends. Data were evaluated for statistical significance with one-way ANOVA. A p-value of 0.05 or less was considered as statistically significant.

\section{Results}

\section{Effects of $\mathrm{H}_{2} \mathrm{O}_{2}$ on Cell Toxicity}

In order to determine the cytotoxic dose of $\mathrm{H}_{2} \mathrm{O}_{2}$ on AR42J cells, cells were exposed for $24 \mathrm{~h}$ to a graded dose of $\mathrm{H}_{2} \mathrm{O}_{2}$. The percent cytotoxicity as determined by $\mathrm{LDH}$ release is shown in Figure 1. In untreated control cells the percent of LDH release was $5.4 \pm 1.1 \%$ while cells exposed to $20 \mu \mathrm{M} \mathrm{H}_{2} \mathrm{O}_{2}$ it was $6.7 \pm 3.9 \%$. This value was not significantly different from the control. As the concentration of $\mathrm{H}_{2} \mathrm{O}_{2}$ increased beyond $20 \mu \mathrm{M}$, the percentage of cytotoxic cells was increased. With $100 \mu \mathrm{M} \mathrm{H}_{2} \mathrm{O}_{2}$, it was 28.0 $\pm 0.3 \%$. This is not surprising since it has been reported that EL-4 murine lymphoma cells exposed to $\mathrm{H}_{2} \mathrm{O}_{2}$ doses beyond $20 \mu \mathrm{M}$, increased number of cytotoxic cells was found by Zhou et al [20]. Thus we have used this noncytotoxic concentration of $20 \mu \mathrm{M}$ of $\mathrm{H}_{2} \mathrm{O}_{2}$ in all the subsequent studies.

\section{Induction of lipid peroxidation by $\mathrm{H}_{2} \mathrm{O}_{2}$ and nicotine in AR42J cells}

To determine whether $\mathrm{H}_{2} \mathrm{O}_{2}$ and nicotine would affect the cell's ability to accumulate reactive oxygen species as measured by the production of malondialaldehyde (MDA) within the cells, cells were treated with either $\mathrm{H}_{2} \mathrm{O}_{2}(20 \mu \mathrm{M})$ for $15 \mathrm{~min}$ or with nicotine $(100 \mu \mathrm{M})$ for 3 min, a non cytotoxic dose determined earlier [10]. Cell lysates were used for the measurement of MDA production as described in the Materials and Methods section. As shown in Figure 2, the concentration of MDA measured in cells exposed to $\mathrm{H}_{2} \mathrm{O}_{2}$ or nicotine were $0.28 \pm 0.02 \mu \mathrm{mol} /$ $\mathrm{mg}$ and $0.26 \pm 0.02 \mu \mathrm{mol} / \mathrm{mg}$, respectively. These values 


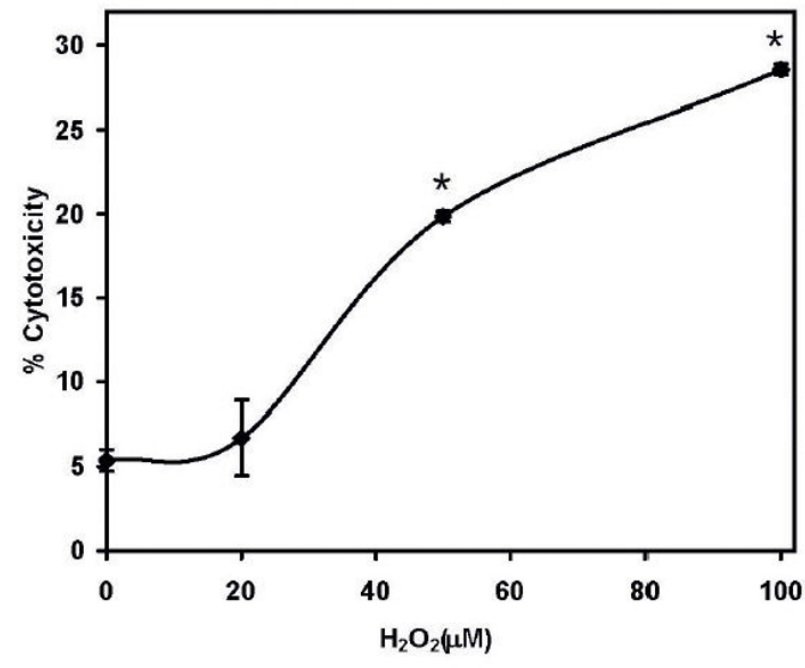

Figure I

Measurement of cytotoxic effect of $\mathrm{H}_{2} \mathrm{O}_{2}$. The cells were exposed to $\mathrm{H}_{2} \mathrm{O}_{2}$ in the dose range of $\mathrm{I0}-100 \mu \mathrm{M}$. A BioVision LDH-Cytotoxiciy Assay Kit (Mountain View, CA) was used, and the absorbance was measured after $24 \mathrm{hr}$ incubation in 96-well plates at a wavelength of $495 \mathrm{~nm}$. The percentage cytotoxicity was calculated as the ratio of absorptions of wells treated with $\mathrm{H}_{2} \mathrm{O}_{2}$ and untreated wells; $\mathrm{N}=8, *, \mathrm{P}<0.05$, significantly different from the uncxposed control.

were significantly higher than the value of $0.11 \pm 0.01$ $\mu \mathrm{mol} / \mathrm{mg}$ in control cells $(\mathrm{p}<0.01)$.

\section{Activation of ERK signaling by $\mathrm{H}_{2} \mathrm{O}_{2}$}

It has been shown that in other cells, ERK1/2 is activated by $\mathrm{H}_{2} \mathrm{O}_{2}$ treatment $[20,21]$. To determine the effects of $\mathrm{H}_{2} \mathrm{O}_{2}$ on ERK1/2 activation in AR42J cells, the cells were exposed to $\mathrm{H}_{2} \mathrm{O}_{2}(20 \mu \mathrm{M})$ for various times. Cell lysates were prepared and measured for total and p-ERK1/2 activation employing the specific antibodies to total and pERK1/2 and analyzed by Western blots. With $20 \mu \mathrm{M}$ $\mathrm{H}_{2} \mathrm{O}_{2}$, a 3 fold increase in band intensity was observed at 15 min which was significantly higher $(p<0.02)$ when compared to the control cells (Figure 3A). Expressing band intensity as the fold increase above the control, a steady increase in p-ERK activation was observed with increasing concentrations of $\mathrm{H}_{2} \mathrm{O}_{2}$ at $15 \mathrm{~min}$ of incubation, attaining a 7-fold increase with $100 \mu \mathrm{M} \mathrm{H}_{2} \mathrm{O}_{2}$ (Fig. 3B). Total ERK1/2 in all instances showed no alteration with $\mathrm{H}_{2} \mathrm{O}_{2}$ incubation and indicated a uniformity of loading of the wells with samples.

\section{Response of $\mathrm{H}_{2} \mathrm{O}_{2}$ and nicotine in activation of ERK signaling in AR42J cells}

The non cytotoxic dose of hydrogen peroxide as determined from the study described above was used in this

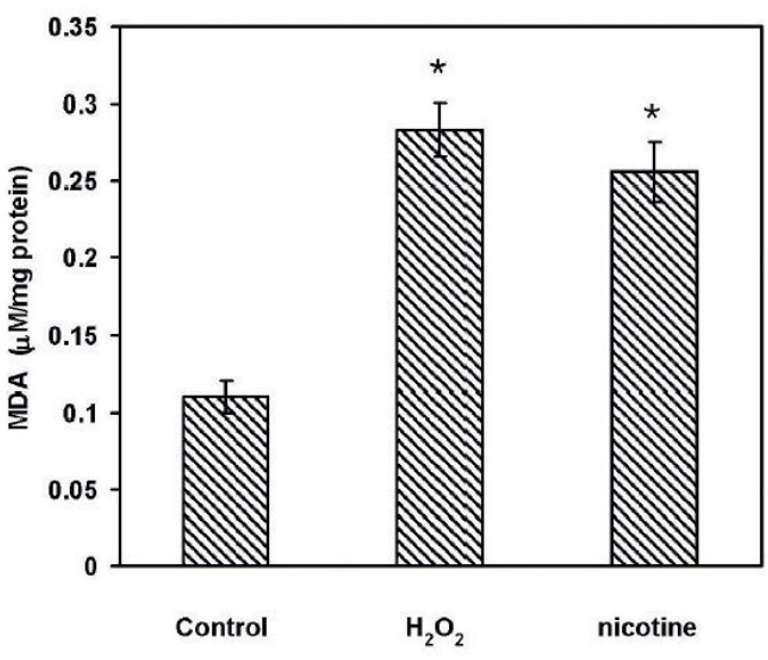

Figure 2

Lipid peroxidation represented by MDA concentration in AR42J cells. Control untreated cells, cells exposed to $20 \mu \mathrm{M} \mathrm{H}_{2} \mathrm{O}_{2}$ for 15 min or to $100 \mu \mathrm{M}$ nicotine for $3 \mathrm{~min}$ were lysed after treatments and the lysates were used in an MDA-586 Assay (Oxis Research, Portland, OR). The values are expressed as $\mu \mathrm{M} / \mathrm{mg}$ protein in $y$-axis. The vertical bar represents treatments with $\mathrm{H}_{2} \mathrm{O}_{2}$ or nicotine, $\mathrm{N}=5$, *, $\mathrm{P}<$ 0.05 , significantly different from the uncxposed control.

study along with the non-cytotoxic dose of nicotine reported earlier from this laboratory [10]. The concentration of nicotine used in this study was $100 \mu \mathrm{M}$ with an incubation time of $3 \mathrm{~min}$. A comparison of p-ERK1/2 activation of cells exposed to nicotine or $\mathrm{H}_{2} \mathrm{O}_{2}$ is shown in Figure 4 . The data show that there were increases in $\mathrm{p}$ ERK1/2 activation in cells exposed to $100 \mu \mathrm{M}$ nicotine for $3 \mathrm{~min}$ or $20 \mu \mathrm{M} \mathrm{H}_{2} \mathrm{O}_{2}$ for $15 \mathrm{~min}$. The band intensities expressed as the fold increase were 2 fold higher with both nicotine and $\mathrm{H}_{2} \mathrm{O}_{2}$ and were significantly higher when compared to the unexposed cells $(\mathrm{p}<0.05)$.

\section{Cytoplasmic localization of activated p-ERKI/2 by $\mathrm{H}_{2} \mathrm{O}_{2}$ and nicotine as determined by immunofluorescence}

Activation of pERK1/2 in AR42J cells by nicotine and $\mathrm{H}_{2} \mathrm{O}_{2}$ were onfirmed by immunofluorescence study after exposing the cells to nicotine or $\mathrm{H}_{2} \mathrm{O}_{2}$, and probing the fixed cells with antibody to p-ERK1/2. As shown in Figure 5 , immunostaining revealed that the p-ERK $1 / 2$ signals were distributed throughout the cell cytoplasm with considerably higher fluorescent intensities of p-ERK1/2 observed when cells were treated with nicotine or $\mathrm{H}_{2} \mathrm{O}_{2}$. Cells not exposed to nicotine or $\mathrm{H}_{2} \mathrm{O}_{2}$, on the other hand, showed less fluorescent intensities compared with treated cells. The immunofluorescence data supported the observation of increased induction of pERK1/2 by nicotine and $\mathrm{H}_{2} \mathrm{O}_{2}$ as analyzed by Western Blot. 
A
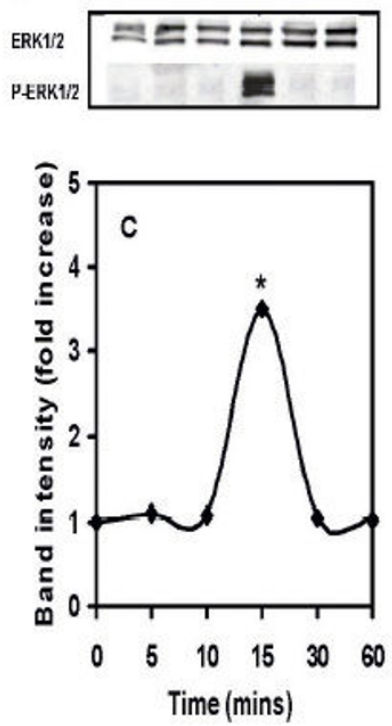

B
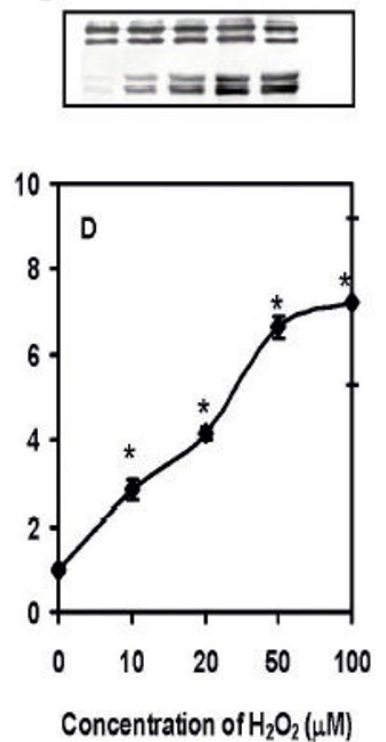

Figure 3

Dose and time dependent induction of ERKI/2 in AR42J cells. Cell lysates were loaded onto an SDS gel, separated by electrophoresis, blocked in I\% fat free milk and probed with antibodies to total and phosphorylated ( $\mathrm{P}$ ) ERKI/2. Horseradish peroxidase-coupled anti IgG was used as a secondary antibody. Bands were visualized with ECL-plus and quantified using a STORM Imager. The data shown as means \pm SEM of $n=5$ experiments. A: Induction of ERKI/2 in cells exposed to $20 \mu \mathrm{M} \mathrm{H}_{2} \mathrm{O}_{2}$ for 10-60 min compared to control untreated cells. $\mathbf{B}$ : Induction of ERK in cells exposed to $10-20 \mu \mathrm{M} \mathrm{H}_{2} \mathrm{O}_{2}$ for $15 \mathrm{~min}$. C: Band intensity showing the fold increase in the time dependent induction of ERKI/2. D: Band intensity showing the fold increase in the dose dependent induction of ERK I/2.

\section{Effects of $\mathrm{H}_{2} \mathrm{O}_{2}$ or nicotine on AR42] cell Proliferation}

In order to compare the nicotine-induced ERK1/2 activation in the growth of AR42J cells with that of $\mathrm{H}_{2} \mathrm{O}_{2}$ induced ERK1/2, cell proliferation experiments were performed. The details of the experiments were described in the Materials and Methods section. The cell proliferation was evaluated from 24-96 h of incubation in media containing $0.05 \%$ serum and using an MTT assay kit. The absorbance was measured at $450 \mathrm{~nm}$. As shown in Figure 6 , there was a significant difference in proliferation pattern between nicotine exposed cells; the cells treated with $\mathrm{H}_{2} \mathrm{O}_{2}$ or unexposed control cells. The maximum proliferation occurred at $48 \mathrm{~h}$ interval and then declined at later periods. The absorbance for nicotine exposed cells at $48 \mathrm{~h}$ interval was $0.3 \pm 0$ arbitrary units while that for controls it was $0.2 \pm 0.0$ arbitrary units $(\mathrm{p}<0.05)$. There was no sig-

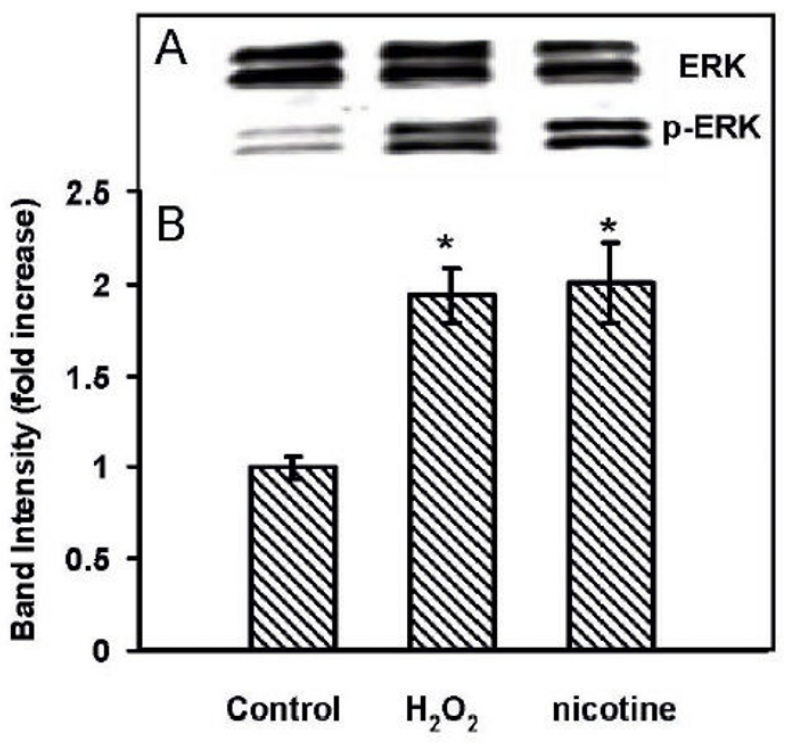

Figure 4

Induction of ERKI/2 in AR42J cells exposed to nicotine or $\mathbf{H}_{2} \mathbf{O}_{2}$. Control untreated cells, cells exposed to 20 $\mu \mathrm{M} \mathrm{H}_{2} \mathrm{O}_{2}$ for 15 min or $100 \mu \mathrm{M}$ nicotine 3 min were lysed and the lysates were used for Western blotting. A: Western blot visualization with ECL-plus using STORM Imaging software. B: Band intensity showing the fold increase as mean \pm SEM of $\mathrm{n}=5$ experiments. $*, \mathrm{P}<0.05$, significantly different from the uncxposed control.

nificant difference between the proliferation observed for cells exposed to $\mathrm{H}_{2} \mathrm{O}_{2}$ and the control cells.

\section{Influence of $\mathrm{H}_{2} \mathrm{O}_{2}$ and nicotine Cell Function}

The effects $\mathrm{H}_{2} \mathrm{O}_{2}$ and nicotine on cell function were assessed by determining their ability to stimulate the secretagogue induced enzyme release. The concentrations of nicotine and $\mathrm{H}_{2} \mathrm{O}_{2}$ used in the studies were $100 \mu \mathrm{M}$ and $20 \mu \mathrm{M}$ for a time of exposure of 3 and $15 \mathrm{~min}$ respectively. The washed cells were incubated with or without cholecystokinin (CCK) at their maximal stimulating concentration of $10^{-10} \mathrm{M}$ as reported earlier [22]. The release of amylase in response to CCK was measured as percent of initial content and is shown in Figure 7. The percent of amylase released from the cells treated with nicotine was $(18.2 \pm 1.8 \%$ of initial content) and it was significantly higher from the percent amylase released from either the control cells $(9.5 \pm 1.0 \%$ of initial content, or from the $\mathrm{H}_{2} \mathrm{O}_{2}$ treated cells $(8.2 \pm 1.1 \%$ of initial content, $\mathrm{p}<0.05)$.

\section{Discussion}

The effects of nicotine on cell proliferation and secretion has been reported in this cell line [10]. The current study re-examined the effects of nicotine in the same cell system 

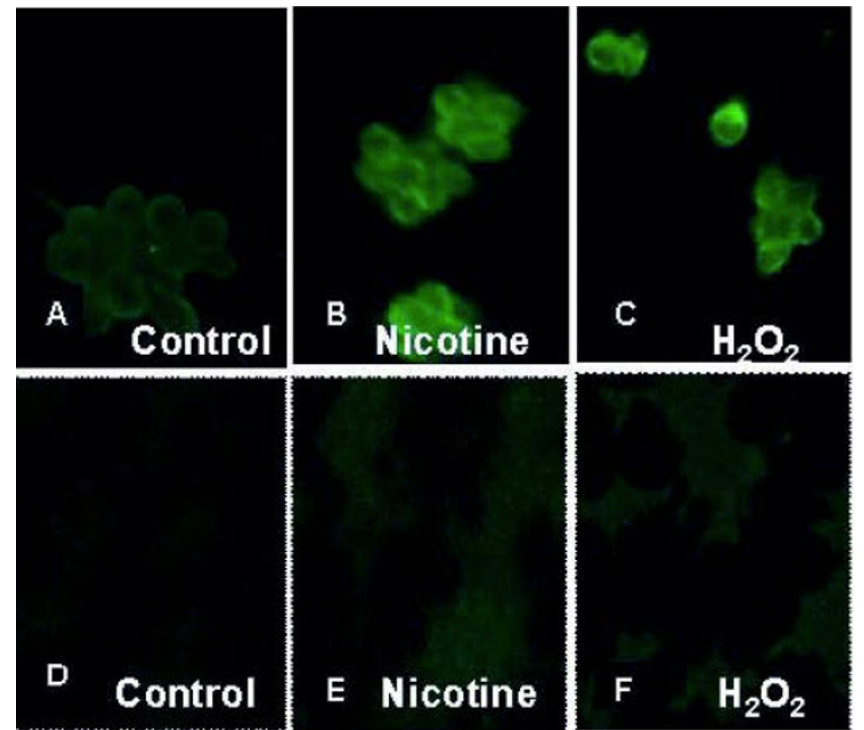

Figure 5

Induction of p-ERKI/2 in AR42J cells as indicated by immunohistochemistry. AR42 J cells were grown and treated with $\mathrm{I} 00 \mu \mathrm{M}$ nicotine for $3 \mathrm{~min} ; 20 \mu \mathrm{M} \mathrm{H} \mathrm{H}_{2} \mathrm{O}_{2}$ for $\mathrm{I} 5$ $\mathrm{min}$. The cells were fixed with paraformaldehyde and treated with antibody to p-ERKI/2 for I h. After washing, the cells were treated with secondary antibody labeled FITC. Slides were observed using a confocal microscope A: Control untreated cells probed with primary antibody to $p$-ERKI/2 B: Cells exposed to nicotine for 3 min probed with primary antibody to $\mathrm{p}$-ERKI/2 C: Cells exposed to $\mathrm{H}_{2} \mathrm{O}_{2}$ for 15 min probed with primary antibody to $\mathrm{P}-\mathrm{ERK} \mathrm{I} / 2$. Negative controls were done by incubating in FITC labeled secondary antibody only. (D - F). D: Control untreated cells. E: Cells exposed to nicotine for $3 \mathrm{~min}$. F: Cells exposed to $\mathrm{H}_{2} \mathrm{O}_{2}$ for $15 \mathrm{~min}$. The experiment was repeated in a set of four under each treatment.

with the added exposure to hydrogen peroxide to determine whether nicotine-induced effects on these cells are regulated via oxidative stress pathway. Thus hydrogen peroxide was selected as a well known marker for oxidative damage. Previous studies have shown that exposure of human osteosarcoma cell line to 1-10 $\mathrm{mM} \mathrm{H}_{2} \mathrm{O}_{2}$ induced reactive oxygen species (ROS) formation, DNA damage, dysfunction of the mitochondrial membrane potential, and early apoptotic changes in this cell line [23]. Since the presence of excessive ROS is known to cause cellular damage by hydroxyl radical attack [24] it was imperative to perform dose response studies with $\mathrm{H}_{2} \mathrm{O}_{2}$.

Cell cytotoxicity experiments have been first performed to determine the effects of $\mathrm{H}_{2} \mathrm{O}_{2}$ at dose-range from $10-100$ $\mu \mathrm{M}$. The results show that for concentrations beyond 20 $\mu \mathrm{M}$, the percentage cytotoxicity was significantly higher than the control and as high as greater than 20\%. Other studies have also confirmed an increase in cell toxicity

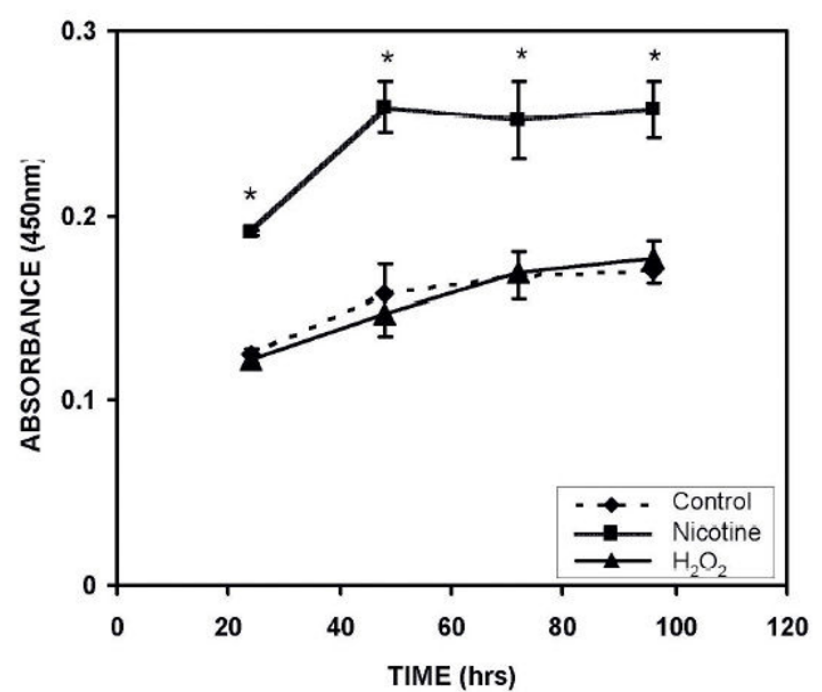

Figure 6

The effect of nicotine or hydrogen peroxide on the proliferation of AR42J cells. The cells were plated in 96well plates and allowed to attach overnight before transferring to $0.05 \%$ serum media for $10-12 \mathrm{~h}$ before beginning of the study. The cells were then treated with $100 \mu \mathrm{M}$ nicotine or $20 \mu \mathrm{M} \mathrm{H}_{2} \mathrm{O}_{2}$ and the proliferation measured at 24-96 h using a cell counting kit from Dojindo Molecular Technologies according to manufacturer's instructions. The data points represent mean \pm SEM of 5 experiments. $\diamond,--$ control unexposed cells; , $\square$--- Nicotine treated; $\boldsymbol{\Delta}$--, $\mathrm{H}_{2} \mathrm{O}_{2}$ treated. *, $\mathrm{P}<0.05$, significantly different from the uncxposed control.

beyond $20 \mu \mathrm{M}$ [25]. Thus, in order to avoid any cell injury and to maintain the cells within the physiological range, this concentration of $\mathrm{H}_{2} \mathrm{O}_{2}$ was selected for the current study.

Lipid peroxidation occurs through free radical attacks of poly-unsaturated fatty acids leading to formation of lipid hydroperoxides as well as conjugated dienes and aldehydes such as malondialdehyde (MDA). In order to investigate whether nicotine induces the generation of oxygen free radicals within the cell, the lipid peroxidation was measured in response to nicotine and $\mathrm{H}_{2} \mathrm{O}_{2}$. The data from our experiments showed that both nicotine and $\mathrm{H}_{2} \mathrm{O}_{2}$ had significant increases in the concentrations of MDA formation as compared to the control untreated cells suggesting that both nicotine and $\mathrm{H}_{2} \mathrm{O}_{2}$ induced ROS formation in AR42J cells. It has been shown that ROS formation above a critical level in oligodendrocytes is followed by an increase in anti-oxidant enzymes possibly to scavenge oxidative by products such as $\mathrm{H}_{2} \mathrm{O}_{2}$ [26-28]. This mechanism is important for cell survival [28]. In this study we show that the concentration of hydrogen peroxide that induced MDA formation also induced the activa- 


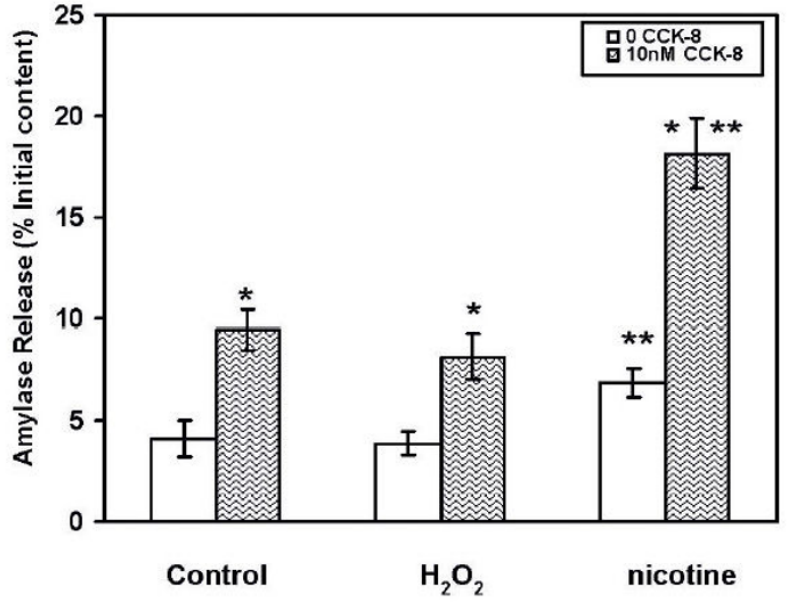

\section{Figure 7}

Comparison of cell function of AR42J cells when exposed to nicotine or $\mathrm{H}_{2} \mathrm{O}_{2}$. The cells were treated with $100 \mu \mathrm{M}$ nicotine for 3 min or $20 \mu \mathrm{M} \mathrm{H}_{2} \mathrm{O}_{2} I 5 \mathrm{~min}$. Cells were subsequently washed with Hepes-Ringer and incubated at $37^{\circ} \mathrm{C}$ with or without CCK-8 (10 nM) for 30 min. Amylase released into the incubation medium was measured with procion yellow starch as a substrate. The data are expressed as percent initial content and represent mean \pm SEM of 5 experiments. open bar---control unexposed; hatched bar---CCK-8 stimulated; *, $\mathrm{p}<0.05$, significantly different from the control; **, $\mathrm{p}<0.05$, significantly different from $\mathrm{H}_{2} \mathrm{O}_{2}$ exposed cells.

tion of p-ERK1/2 signaling (Figure 3). These results are consistent with the data on p-ERK1/2 activation as reported in cultured endothelial cells in which peak responses of p-ERK activation is shown to occur after 15 min of exposure followed by its return to baseline at 60 min [29]. In our study we have also observed that the activation of pERK-1/2 by $\mathrm{H}_{2} \mathrm{O}_{2}$. These observations have been confirmed further by co-localization of p-ERK1/2 within the cytosol by immunoflorescence study.

Since ERK is known as a signal for mitogen-activated protein kinase (MAPK) pathway and has been shown to be involved in growth, differentiation and development in mammalian system [30], we sought to investigate its role following its induction by nicotine or hydrogen peroxide in AR42J cell proliferation employing MTT assay as reported earlier [10]. Our data show that while nicotine does promote significant growth within the first 48 hours of incubation in low serum media, $\mathrm{H}_{2} \mathrm{O}_{2}$ treated cells, on the other hand, do not show such an increase in proliferation and its effects on cell proliferation is similar to that of untreated cells (Figure 5). It has been suggested that the induction of p-ERK1/2 by $\mathrm{H}_{2} \mathrm{O}_{2}$ is a cell specific response [31], where $\mathrm{H}_{2} \mathrm{O}_{2}$ may be able to utilize multiple path- ways to produce mitogenic effects depending on the cell type. Thus we surmise that even though the cells do not proliferate at a faster rate with $\mathrm{H}_{2} \mathrm{O}_{2}$ as observed for the cells exposed to nicotine, the rate of proliferation by $\mathrm{H}_{2} \mathrm{O}_{2}$ is similar to that of the control untreated cells. These complex regulatory mechanisms have been described previously by Watanabe et al [21], and others [32] Thus it is possible that induction of ERK signaling by $\mathrm{H}_{2} \mathrm{O}_{2}$ may be critical in the regulation of cellular protection in the early stage of cell response to oxidative stress. One other interpretation may be that $\mathrm{H}_{2} \mathrm{O}_{2}$ induced p-ERK activation and MDA formation are not involved in cellular proliferation.

Cell function studies have been conducted by stimulating the cells with a previously determined maximal dose of cholecystokinin (CCK). These experiments are aimed to determine whether there are any differences in cell function when they are exposed to nicotine or $\mathrm{H}_{2} \mathrm{O}_{2}$ at their optimum concentrations. While the CCK-induced amylase secretion with nicotine exposure is significantly higher than the unexposed cells, there is no increase in amylase secretion by $\mathrm{H}_{2} \mathrm{O}_{2}$ over and above that of control. It has been shown that CCK can evoke marked changes in pancreatic acinar cell mitochondrial activity and that CCK-8 evoked responses are blocked by $\mathrm{H}_{2} \mathrm{O}_{2}$ [33]. Impairment of mitochondrial activity in the presence of $\mathrm{H}_{2} \mathrm{O}_{2}(1 \mathrm{mM})$ may represent a mechanism by which cellular damage can occur leading to its dysfunction and pathology. The dose of $20 \mu \mathrm{M}$ of $\mathrm{H}_{2} \mathrm{O}_{2}$ used in this study is nontoxic and therefore, the data from our studies showing normal cell function appear consistent with those observations.

$\mathrm{H}_{2} \mathrm{O}_{2}$ is a known oxidative agent and is used here as a biomarker by which its effect on AR42J cells can be directly compared to the effects of nicotine following its exposure. Functional and cell proliferation studies show a significant difference in the effects between nicotine and $\mathrm{H}_{2} \mathrm{O}_{2}$ on AR42J cells. This indicates that while nicotine exposure does result in the production of ROS within the cells, there are certain other key factors induced by nicotine that differentiates its effects from that of $\mathrm{H}_{2} \mathrm{O}_{2}$. In the current study, we have aimed to show that one of these key factors for cell injury is in the production or ROS. Since ROS has been shown to cause DNA single strand breakdown [34], it is reasonable to consider further investigation of the role of nicotine in signal transduction pathways and its oxidative role in pancreatic cell injury. In invivo studies, Wittel et al [35] investigated the effect of cigarette smoke inhalation in rats. Their studies showed that morphological damage to pancreas induced by inhalation of cigarette smoke may likely be mediated by alteration of acinar cell function. Our studies in in-vitro cell culture using nicotine as marker supports the observation made by Wittel et al [35]. 


\section{Authors' contributions}

AW carried out all experiments, data analysis. and produced a draft of the manuscript. KBU participated in the design of the study and veified the statistical analysis. PC conceived and directed the study. All authors read and approved the final manuscript.

\section{Acknowledgements}

This study was supported, in part, by funds from Central Arkansas Veterans Healthcare System and the University of Arkansas for Medical sciences. The authors thank Dr. Chhanda Bose for her valuable discussion and technical suggestions. A part of this study was presented at the Annual Meeting of The American Gastroenterological Association, Digestive Disease Week, held in Los Angeles, California, May 20-25, 2006.

\section{References}

I. Mokdad AH, Marks JS, Stroup DF, Gerberding JL: Actual causes of death in the United States, 2000. JAMA 2004, 29 I:1238-1245.

2. Morbidity and Mortality Weekly Report, Tobacco use-United States. 1900-1999. MMWR Morb Mortal Wkly Rep 1999, 48:986-993.

3. Talamini G, Bassi C, Falconi M, Sartori N, Salvia R, Rigo L, Castagnini A, Di FV, Frulloni L, Bovo P, Vaona B, Angelini G, Vantini I, Cavallini $G$, Pederzoli P: Alcohol and smoking as risk factors in chronic pancreatitis and pancreatic cancer. Dig Dis Sci 1999, 44: $|303-| 3||$

4. Lin Y, Tamakoshi A, Hayakawa T, Ogawa M, Ohno Y: Cigarette smoking as a risk factor for chronic pancreatitis: a case-control study in Japan. Research Committee on Intractable Pancreatic Diseases. Pancreas 2000, 21:109-II4.

5. Rayford PL, Chowdhury P: Mecamylamine, a nicotinic receptor channel antagonist, affects amylase secretion by isolated pancreatic acinar cells. J Assoc Acad Minor Phys 200I, I 2: I05- 108.

6. Chowdhury P, MacLeod S, Udupa KB, Rayford PL: Pathophysiological effects of nicotine on the pancreas: an update. Exp Biol Med (Maywood) 2002, 227:445-454.

7. Wetscher G], Bagchi M, Bagchi D, Perdikis G, Hinder PR, Glaser K, Hinder RA: Free radical production in nicotine treated pancreatic tissue. Free Radic Biol Med 1995, 18:877-882.

8. Yildiz D, Liu YS, Ercal N, Armstrong DW: Comparison of pure nicotine- and smokeless tobacco extract-induced toxicities and oxidative stress. Arch Environ Contam Toxicol 1999, 37:434-439.

9. Park BK, Chung JB, Lee JH, Suh JH, Park SW, Song SY, Kim H, Kim $\mathrm{KH}$, Kang JK: Role of oxygen free radicals in patients with acute pancreatitis. World J Gastroenterol 2003, 9:2266-2269.

10. Bose C, Zhang H, Udupa KB, Chowdhury P: Activation of p-ERKI/ 2 by nicotine in pancreatic tumor cell line AR42J: effects on proliferation and secretion. Am J Physiol Gastrointest Liver Physiol 2005, 289:G926-G934.

11. Chowdhury P, Bose C, Udupa K: Nicotine induced proliferation of isolated rat pancreatic acinar cells: Effect of cell signaling and function. Cell Proliferation 2007, 40:|25-|4|.

12. Chiarugi P: Reactive oxygen species as mediators of cell adhesion. Ital J Biochem 2003, 52:28-32.

13. Ganesh PC, Rao SMN: Evidence for oxidant stress in chronic pancreatitis. Indian J Gastroenterol 1999, 18:156-157.

14. Piperakis SM, Visvardis EE, Sagnou M, Tassiou AM: Effects of smoking and aging on oxidative DNA damage of human lymphocytes. Carcinogenesis 1998, 19:695-698.

15. Christophe J: Pancreatic tumoral cell line AR42J: an amphicrine model. Am J Physiol 1994, 266:G963-G97I.

16. Soulsby ME, Phillips B, Chowdhury P: The effects of a soy-protein diet o elevated brain lipid peroxide levels induced by simulated weightlessness. Annals of Clin \& Lab Sci 2004, 34:103-106.

17. Chowdhury P, Soulsby M, Kim K: L-carnitine influence on oxidative stress induced by hind-limb unloading in Adult Rats. Aviat Space Environ Med 2007, 78:554-556.

18. Bradford MM: A rapid and sensitive method for the quantitation of microgram quantities of protein utilizing the principle of protein-dye binding. Anal Biochem 1976, 72:248-254.
19. Jung DH: Preparation and application of Procion Yellow starch for amylase assay. Clin Chim Acta 1980, 100:7-II

20. Zhou Y, Wang Q, Evers BM, Chung DH: Signal transduction pathways involved in oxidative stress-induced intestinal epithelial cell apoptosis. Pediatr Res 2005, 58: I I 92 - I I 97.

21. Watanabe N, Zmijewski JW, Takabe W, Umezu-Goto M, Le Goffe C Sekine A, Landar A, Watanabe A, Aoki J, Arai H, Kodama T, Murphy MP, Kalyanaraman R, Darley-Usmar VM, Noguchi N: Activation of mitogen-activated protein kinases by lysophosphatidylcholine-induced mitochondrial reactive oxygen species generation in endothelial cells. Am J Pathol 2006, 168:737-1748.

22. Chowdhury P, Hosotani R, Rayford PL: Inhibition of CCK or carbachol stimulated amylase release by nicotine. Life Sciences 1989, 45:2163-2168.

23. Ogawa $Y$, Kobayashi T, Nishioka A, Kariya S, Ohnishi T, Hamasato $S$, Seguchi $\mathrm{H}$, Yoshida $\mathrm{S}$ : Reactive oxygen species-producing site in radiation-induced apoptosis of human peripheral $\mathbf{T}$ cells: involvement of lysosomal membrane destabilization. Int J Mol Med 2004, 13:69-73.

24. Riley PA: Free radicals in biology: oxidative stress and the effects of ionizing radiation. Int J Radiat Biol 1994, 65:27-33.

25. lijima R, Takahashi H, Namme R, Ikegami S, Yamazaki M: Novel biological function of sialic acid ( $\mathbf{N}$-acetylneuraminic acid) as a hydrogen peroxide scavenger. FEBS Lett 2004, 56I:163-166.

26. Baud O, Greene AE, Li J, Wang H, Volpe JJ, Rosenberg PA: Glutathione peroxidase-catalase cooperativity is required for resistance to hydrogen peroxide by mature rat oligodendrocytes. J Neurosci 2004, 24: I53I-I540.

27. Meiners S, Ludwig A, Lorenz M, Dreger H, Baumann G, Stangl V, Stangl K: Nontoxic proteasome inhibition activates a protective antioxidant defense response in endothelial cells. Free Radic Biol Med 2006, 40:2232-224I.

28. Martindale JL, Holbrook NJ: Cellular response to oxidative stress: signaling for suicide and survival. I Cell Physiol 2002, 192:I-15.

29. Yang $B$, Oo TN, Rizzo V: Lipid rafts mediate $\mathbf{H}_{2} \mathbf{O}_{2}$ prosurvival effects in cultured endothelial cells. FASEB J 2006, 20:150I-I503.

30. Cobb MH: MAP kinase pathways. Prog Biophys Mol Biol 1999 , 7I:479-500.

31. Zhang J, Jin N, Liu Y, Rhoades RA: Hydrogen peroxide stimulates extracellular signal-regulated protein kinases in pulmonary arterial smooth muscle cells. Am J Respir Cell Mol Biol 1998, 19:324-332.

32. Song HJ, Lee TS, Jeong JH, Min YS, Shin C, Sohn UD: Hydrogen peroxide-induced extracellular signal-regulated kinase activation in cultured feline ileal smooth muscle cells. J Pharmacol Exp Ther 2005, 3 | 2:39|-398.

33. Granados MP, Salido GM, Pariente JA, Gonzales A: Effect of $\mathbf{H}_{\mathbf{2}} \mathbf{O}_{2}$ on CCK-8-evoked changes in mitochondial activity in isolated mouse pancreatic acinar cells. Biology of the Cell 2005, 97:847-856.

34. Weitberg $A B$, Corvese $D$ : Oxygen radicals potentiate the genetic toxicity of tobacco-specific nitrosamines. Clin Genet 1993, 43:88-9|

35. Wittel UA, Pandey KK, Andranifahanana M, Johansson SL, Cullen DM, Akhter MP, Brand RE, Prokopczyk B, Batra SK: Chronic pancreatic inflammation induced by environmental tobacco smoke inhalation in rats. Am J Gastroenterol 2006, I01:148-159. 